\title{
Socio-Economic Characteristics and Animal Feed Resources of Ruminant Farmers in Katsina State, Nigeria
}

\author{
${ }^{1 *}$ ARUWAYO, A; ${ }^{1}$ AHMED, KS; ${ }^{2}$ MUHAMMAD, IR \\ ${ }^{*}$ Department of Animal Science, Faculty of Agriculture and Agricultural Technology, Federal University Dutsin-ma, P.M.B 5001, Post \\ Code 821221, Dutsin-ma, Katsina State, Nigeria \\ ${ }^{2}$ Department of Animal Science, Faculty of Agriculture, Bayero University, Post code 700231 Kano, Nigeria \\ *Corresponding Author Email: aruwayoadebayo@gmail.com
}

\begin{abstract}
The survey was conducted to identify common ruminant feed resources in and around Dutsin-ma, Sheme, Faskari in Katsina state and investigate the socio-economic characteristics of ruminant farmers, farming system, feed types, sources, availability, price and major constraints in sourcing for non-conventional feed and feedstuff using a structured questionnaire system. The results of the survey showed that all respondents are male and married with crop farming as their primary occupation. $46.67 \%$ of the farmers had primary education with 6-10 years of livestock farming experience. The largest percentage $(66.77 \%)$ of the farmers adopts intensive farming system. Feed resources were less expensive during harvest and expensive long after harvest i.e. during the dry season. High feed cost was the major constraints faced in sourcing feed. The feedstuffs were available from August to December and became relatively scarce in January. Respondents improve the nutritive value of the feedstuff by treating them with urea, sugarcane molasses and potassium. Farm residues, home remnants and agro allied waste were shown to have abetted the challenges of scarcity of ruminant feed especially during the dry season of the year. Some of the feedstuffs were not available at some periods of the month, a vivid picture of the time of their availability as shown in research could help the farmers to know when these feedstuffs are available and then buy at cheaper price and store for use at the time of scarcity. This will ultimately reduce cost of feeding and consequently, the cost of production.
\end{abstract}

DOI: https://dx.doi.org/10.4314/jasem.v23i7.26

Copyright: Copyright (C) 2019 Aruwayo et al. This is an open access article distributed under the Creative Commons Attribution License (CCL), which permits unrestricted use, distribution, and reproduction in any medium, provided the original work is properly cited.

Dates: Received: 12 December 2018; Revised: 12 June 2019; Accepted 15 July 2019

Keywords: resources, feed, ruminants, feedstuff

Nigeria has the potential to produce meat from ruminant animals to meet up the animal protein requirements for the entire citizenries. Ruminants' animals are reared in large quantity in Nigeria especially in the northern part. 2011 National Agricultural Sample Survey indicated that Nigeria reported an estimated 19.5 million cattle, 72.5 million goats, 41.3 million sheep and 28,000 camels. This indicates that ruminant constitute the major source of animal protein. According to FAOSTAT (2008), sheep numbers were in excess of one billion $(1,078,200,000)$ while $861,900,000$ goats were produced. The quantity produced of these animals along with meat from other livestock has not been able to satisfy the national protein requirement. Abdu (2003) reported that the level of animal protein consumption is low in Nigeria and is estimated to be about $8 \mathrm{~g}$ per caput per day, about $27 \mathrm{~g}$ less than the minimum requirement recommended by the National Research Council of the United State of America. Among the challenges of production, feed shortage constitutes the greatest of them. The feed shortage has been blamed on high cost of conventional sources of feed ingredients which (Abdu et al., 2006 rated at 70$80 \%$ of total cost production. The main feed sources for ruminants are natural pastures consisting of grasses, legumes and browse species. These depend on rainfall, which fluctuates especially in the northern part of the country where the most of these animals are reared. The resultant low yield and availability of poor quality herbage gives rise to scarcity of energy and protein feedstuffs during the dry season which constitute a major setback to ruminant livestock production in the tropics (Aruwayo and Maigandi, 2013). This has further been worsened by the competition for conventional feed sources by humans. This has resulted in increase in the cost of these feed ingredients like groundnut cake (GNC) and cotton seed cake (CSC) which then leads to increased cost of production. This has impacted negatively of the productivity of the animals. The dependence of ruminant production on conventional feedstuff such as maize, soybean cake, fish meal and others may not be cost effective in present day Nigeria because of rising demand for these ingredients and the irregular supply (Akinmutimi, 2004) and the competition between 
humans and monogastric animals (Adama, 2008; Ajayi et al., 2008; Ukpabi and Abdu, 2009). Efforts made to alleviate these feed shortages which have not yielded the expected result. Identification of available feed resources and the time of their availability in northern part of the country where these ruminants are predominantly reared could be of immense help. This study was then carried in Katsina state which is one of the highest ruminant producing states in Nigeria to describe the socio-economic characteristics of livestock ruminant farmers, identify major feed resources used, determine their availability over months of the year and identify the constraints of feeding ruminant animals in the state.

\section{MATERIALS AND METHOD}

Description of the study area: The study was carried out at Kankia, Faskari and Dutsin-ma local government areas of Katsina state. Katsina state is located some 260 kilometers $(160 \mathrm{~m})$ east of the city of Sokoto and 135 kilometers $(84 \mathrm{~m})$ northwest of Kano state, close to the border with Niger. In 2007, Katsina state estimated population was 5,801,584 (NPC, 2006). The state is known for production of groundnut, cotton, millet and guinea corn and ruminant animal production. It has Latitude of $12^{\circ}$ 59'26.95" $\mathrm{N}$ and Longitude: 7³6'6.37' 'E.

Sampling techniques: A multiple sampling technique was used for the study. Kankiya, Dutsin-ma, and Sheme markets were purposively chosen in Kankia, Faskari and Dutsin-ma local government areas respectively because they are renowned livestock markets. Sixty (60) structured questionnaires were administered to farmers that brought animals for sale with twenty (20) in each of the three markets in their weekly market days.

Statistical Analysis: Data collected were analyzed for descriptive statistics using Statistical Package for Social Science (SPSS) version 20.

\section{RESULTS AND DISCUSSION}

Socio-Economic Characteristics of Ruminant Farmers in Katsina State: The socio-economic characteristics of the ruminant farmers in the study area are shown in Table 1. From Table 1, the age structure of the ruminants producers in the study area showed that $(13.3 \%)$ of them were below 25 years of age, $32.2 \%$ were within the range of 26-30 years, followed by those between the age of 31-35 years $(23.10 \%)$, and $36-40$ years age range accounted for $8.30 \%$ of the respondents, $15 \%$ of them were aged 41 45 years and $8.30 \%$ were between 46 years and above. . The studies revealed that majority of the ruminant famers were within the active age group. This could imply that they could be strong and well-disposed to adoption of modern farming techniques. Olujenyo (2008) stated that the involvement of aged farmers could lead to low production and poor marketing strategies due to outdated methods of farming, lack of awareness of modern feeds, use of traditional tools and species which do not encourage high output and also failing to adopt modern farming system Nganga et al. (2010) reported that the age of farmers is an important factor in livestock production because it may affect the level of rearing and awareness on modern system of rearing. Over aged majority of people may be less productive than those with an average or younger labour force. However, the age distribution of the ruminant producers is important because of experience and decision. The average age of 33 years of the farmers is good enough to have gained experience needed for decision making and improved management of the animals. The survey revealed that all the respondents were males. This was because only males bring the animals to the market for sale. However, the women are involved in the production at home. This report is comparable to Luqman et al. (2006) that revealed that women participates in less physical livestock management practices such as feeding, providing water, cutting of fodder, tethering and cleaning of barns, pens or kraals while men are actively engaged in animal production and marketing. Women are normally in charge of feeding, animals, cleaning of barns, caring for weak animals, among others while men are the main decision makers in the production and marketing activities of the animals.

The survey findings showed that all the respondents were married. This indicates a high degree of responsibility among the respondents which is important in taking sound decision. The marital status could also be an advantage because the wives and children render support in taking care of the animals. Marital status of a farmer is often used to indicate extra labour availability, especially of spouses and children (Epeju, 2010; Okali and Sumberg, 1984). The household size is shown in the table 1 as follows: $28.33 \%$ (3-5), 28.33\% (6-8), 20.0\% (9-11), 5.0\% (1214), $16.67 \%(15-17)$ and $1.67 \%(18-20)$ families including wife and children. The large family size could have positive impact on farming since they may constitute family labour. The study showed all the respondents are involved in other occupation. Crop farming is common to all the respondents in addition to other ones like $13.33 \%$ trading, $8.33 \%$ carpentry, 16.67 tailoring, $1.67 \%$ civil servant, $1.67 \%$ painting and $1.67 \%$ commercial motorcycle and others $(56.67 \%)$ as shown in table 1 . This implies that the farmers would have more resources to support livestock production which could increase their 
productivity and consequently, their standard of living.

Table 1: Socio-Economic Characteristics of Ruminant Farmers in Katsina State

\begin{tabular}{llll}
\hline Variables & Frequency & Percentage & Average \\
\hline AGE & 8 & 13.3 & \\
$=25$ & 19 & 32.0 & \\
$26-30$ & 14 & 23.1 & \\
$31-35$ & 5 & 8.3 & 33.33 \\
$36-40$ & 9 & 15.0 & \\
$41-45$ & 5 & 8.3 & \\
$45-50$ & 60 & 100.0 & 33.33 \\
\hline GE NDER & 0 & 0 & \\
Male & & & \\
Female & 60 & 100 & \\
MARIT AL ST ATUS & 0 & & \\
Married & 0 & & \\
Single & 0 & & \\
Divorced & 0.33 \\
Widow/widower & 0 & & \\
\end{tabular}

\begin{tabular}{|c|c|c|c|}
\hline \\
\hline \multicolumn{4}{|l|}{$\begin{array}{l}\text { OT HE R OCCUPATION } \\
\text { PRIMARY }\end{array}$} \\
\hline $\begin{array}{l}\text { Crop Farming } \\
\text { SECONDARY }\end{array}$ & 60 & 100 & 33.33 \\
\hline Trading & 8 & 13.33 & \\
\hline Carpentry & 5 & 8.33 & \\
\hline Tailoring & 10 & 16.67 & \\
\hline Civil Servant & 1 & 1.67 & \\
\hline Painting & 1 & 1.67 & 0.37 \\
\hline Commercial Motorcycling & 1 & 1.67 & \\
\hline Others & 34 & 56.67 & \\
\hline \multicolumn{4}{|l|}{ HOUSE HOLD SIZE } \\
\hline $3-5$ & 17 & 28.33 & \\
\hline $6-8$ & 17 & 28.33 & \\
\hline $9-11$ & 12 & 20.0 & 8.83 \\
\hline $12-14$ & 3 & 5.0 & \\
\hline $15-17$ & 10 & 16.67 & \\
\hline $18-20$ & 1 & 1.67 & \\
\hline \multicolumn{4}{|l|}{ EDUCATION } \\
\hline Pimary & 28 & 46.67 & \\
\hline Secondary & 10 & 16.67 & 2.25 \\
\hline Tertiary & 1 & 1.67 & \\
\hline Qur'anic & 21 & 35.0 & \\
\hline \multicolumn{4}{|l|}{ LIVE ST OCK } \\
\hline FARMING & 2 & 3.33 & \\
\hline EXPERIENCE & 28 & 46.67 & \\
\hline$=5$ & 13 & 21.67 & 12.7 \\
\hline $6-10$ & 13 & 21.67 & \\
\hline $11-15$ & 2 & 3.33 & \\
\hline $16-20$ & 2 & 3.33 & \\
\hline \multicolumn{4}{|l|}{$21-25$} \\
\hline $26-30$ & & & \\
\hline
\end{tabular}

The study also showed that $46.67 \%$ of the respondents obtain primary education with $1-7$ years of schooling, $16.67 \%$ had secondary education of $4-6$ years of schooling, $1.67 \%$ tertiary education and $35.0 \%$ of them possessed Qur'anic education. The level of education observed in the study could boost their productivity through improved adoption of innovations and skills of the respondents in ruminant production. Education is always valued as a tool of independence to oneself from ignorance and enables the person to play non-traditional roles (Kasanga, 2005). The result of the study indicated that a large proportion of the respondents $(46.67 \%)$ had between 6-10 years of livestock production experience, $21.67 \%$ of them had between 11-15 years of experience, $21.67 \%$ was between $16-20$ years of experience, $3.33 \%$ had between $21-25$ years while $3.33 \%$ had farming experience of between 26-30 years while only $3.33 \%$ had $\leq 5$ years' experience in farming. Experience is of considerable influence on production profitability. This was in agreement with the report by Adamu (1993) that farming experience play significant role in profitability of livestock production

Farming system: The research findings showed in table 3 that $66.67 \%$ of the ruminant producers adopt intensive system of management and $33.33 \%$ adopt semi-intensive system of management. Investigation showed that the farmers adopt this system of farming because of the security challenges and the rustling of animals in the areas of study. This has been revealed to have increased the cost of production. However, bio-security, high production rate and also adequate record keeping are ensured as reported by Adamu, (1993).

Table 3: Distribution of Respondents according to the farming system

\begin{tabular}{lll}
\hline variables & Frequency & Percentage \\
\hline Intensive & 40 & 66.67 \\
Semi intensive & 20 & 33.33 \\
\hline
\end{tabular}

Classification of feed: Table 4 showed the classification of feedstuffs used by the farmers in to feeding the ruminants. From the table, $3.33 \%$ of the use farm residue and home remnants, $35 \%$ of them feed the animals farm residue only, $5 \%$ use home remnant for feeding while $3.33 \%, 8.30 \%$, and $45 \%$ of the respondents adopted farm residue and grazing, home remnant and grazing respectively in feeding their animals.

\begin{tabular}{lll} 
Table 4: Classification of feed & & \\
\hline Variable & Frequency & Percentage \\
\hline Farm residue and home remnants & 2 & 3.33 \\
Farm residues only & 21 & 35.00 \\
Home remnants only & 3 & 5.00 \\
Farm residue and grazing & 2 & 3.33 \\
Home remnant and grazing & 5 & 8.33 \\
Commercial feeds & 27 & 45.00 \\
\hline
\end{tabular}

Non-conventional feedstuff

This indicated that a large percentage of the farmers used commercial feeds which were largely concentrates due to awareness on the importance of 
modern types of feeds that are rich in nutrients. However, the study also revealed that ruminant production also benefit immensely from farm residues that were fed along with the concentrates and were able to mitigate the effect of shortage of feedstuff during period of scarcity.

Home remnants: Table 5 revealed that home remnants fed to the ruminant animals in the area of study. $10 \%$ of the respondents used banana peels, $25 \%$ of them used pineapple supplement, orange waste was $61.67 \%$ while 3.33\% use other home remnants such as watermelon peels, vegetables etc. This indicated that the farmers take advantage of the available resources around them which alleviates the problem of feed shortage. These are however seasonal.

\begin{tabular}{lll}
\multicolumn{3}{c}{ Table 5: Home remnants } \\
\hline Variables & Frequency & Percentage \\
\hline Banana peels & 6 & 10.00 \\
Pineapple supplement & 15 & 25.00 \\
Orange waste & 37 & 61.67 \\
Others & 2 & 3.33 \\
\hline
\end{tabular}

Agro allied waste: The table 6 revealed the type of agro allied waste ruminant producers fed to the animals. 15 respondents $(25.00 \%)$ used rice milling waste, $18(30.00 \%)$ of them used millet husk and 6 respondents $(10.00 \%)$ fed sorghum husk to the ruminants. The study also showed that $4(6.67 \%)$ the respondents fed their animals with soyabean husk, 2 $(6.67 \%)$ of them use palm kernel nut and poultry litter was revealed to be used by $15 \%$ of the farmers. The use of these wastes as feed for the ruminants helps in alleviating disposal challenges and shortage feed especially during the dry seasons of the year.

\begin{tabular}{lll}
\multicolumn{3}{c}{ Table 6: } \\
\hline Variable & Frequency & Percentage \\
\hline Rice milling waste & 15 & 25.00 \\
Millet husk & 18 & 30.00 \\
Sorghum husk & 6 & 10.00 \\
Soybeans husk & 4 & 6.67 \\
Palm kernel nuts & 2 & 3.33 \\
Poultry litter waste & 15 & 25.00 \\
Total & & $\mathbf{1 0 0}$ \\
\hline
\end{tabular}

Feedstuff improvement: The study revealed that the farmers improved the nutrient value of the nonconventional feed stuff. Materials commonly used as shown in research were urea $(45 \%)$, molasses $(30 \%)$, and potassium $(25 \%)$. This reports supports that of Malami et al. (2006) who reported that urea treatment is the major method of supplementation and improving nutrient value especially $\mathrm{CP}$ value of nonconventional feed stuffs.

Constraints of Sourcing for Non-Conventional Feed stuffs: The research revealed in figure 2 that the farmers encounter challenges in sourcing for nonconventional feed stuffs such as high cost of feed $(33 \%)$, transportation problem $(15 \%)$, unavailability of feeds $(20 \%), 30 \%$ inadequate finance $(30 \%)$ while other uncategorized problems was $2 \%$. Various reports such as those of Fakoya and Oloruntoba (2009); Kabore et al. (2011) and Saffu et al. (2009) confirmed these challenges.

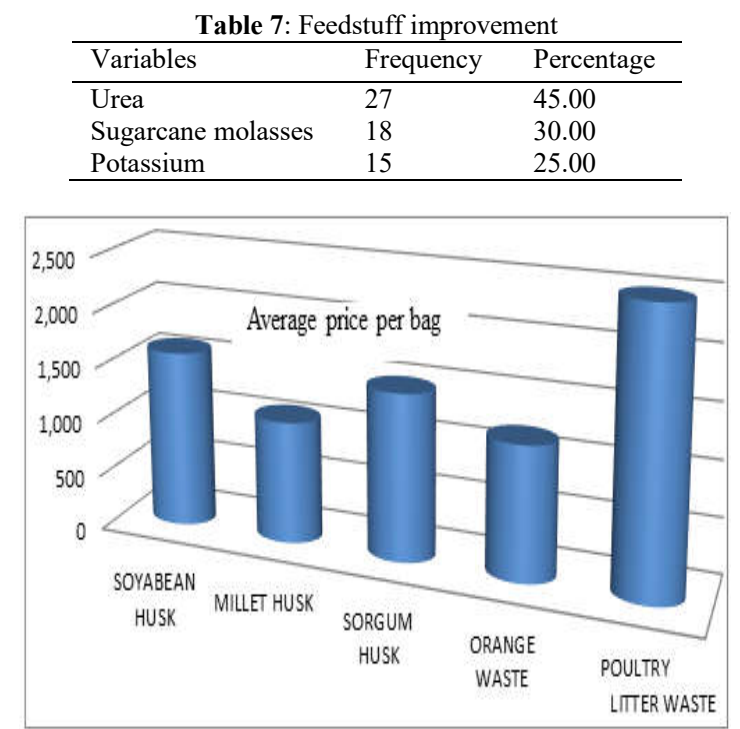

Fig 1. Average price of some selected non-conventional feed in the study Area

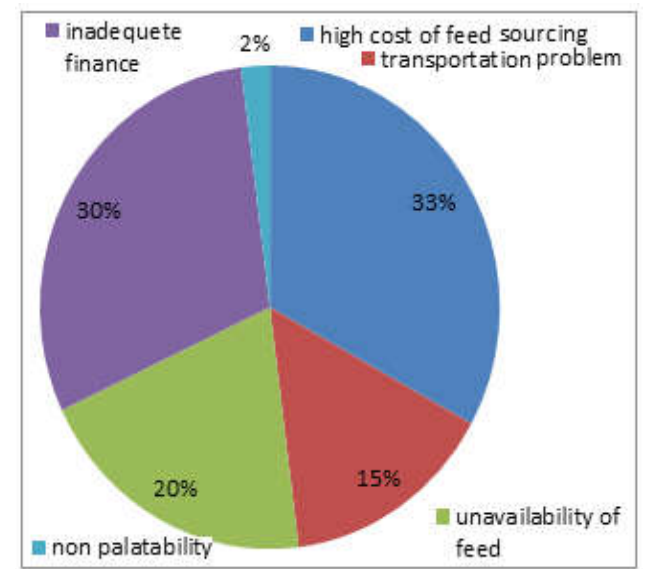

Fig 2: Constraints of Sourcing for Non-Conventional Feed stuffs

Availability of Feedstuff: The availability of feedstuff in the study area was captured in this research. Figure 3 showed the availability of cowpea hay, groundnut cake and ground haulms throughout the year. Cowpea hay and groundnut availability improves at the onset of harvesting in November till March and then become very scarce. However, groundnut hay availability is relatively more stable all through the year. 


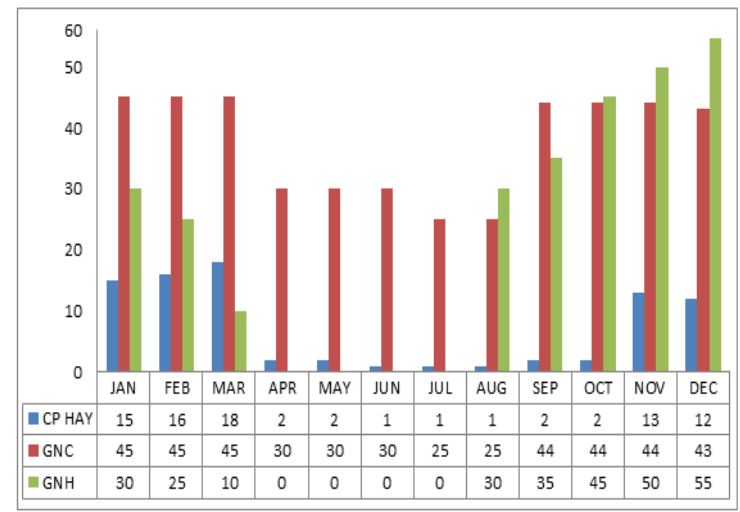

Fig 3: Availability of cowpea hay, groundnut cake and groundnut haulms

The availability of maize stover, potato vine and soybean hay is shown in figure 4. Maize stover became increasingly available from July to December; potato vine was shown to be scarce between the months of June and August while soybean hay was only available in the months of October to December and relatively in the months of January and February.

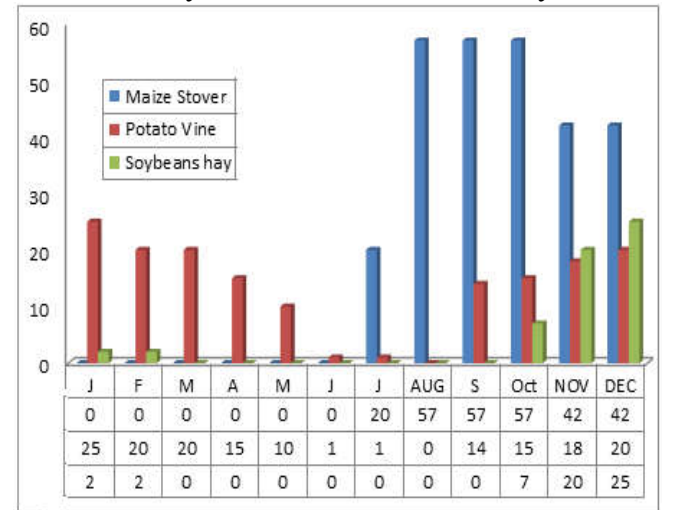

Fig 4: Availability of Maize Stover, Potato Vine and Soybeans hay

In figure 5, maize offal and soybean hay were shown to be readily available all through the year but lower in availability in the months of April to June while Millet stover was only obtainable in the months of August to December.

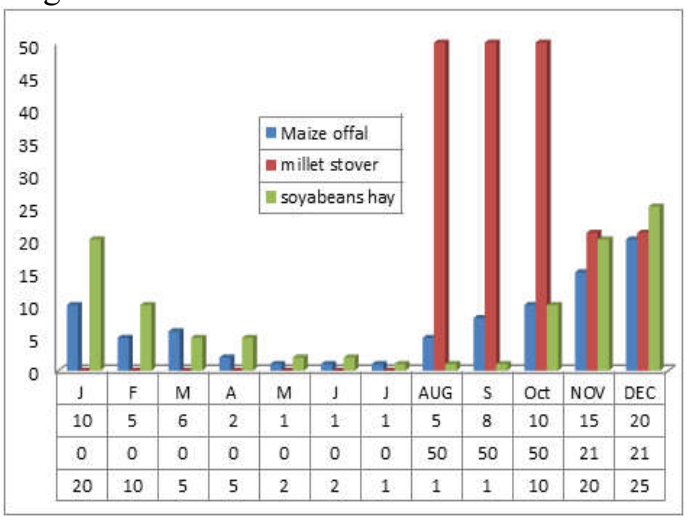

Fig 5: Availability of maize offal, millet stover, soyabean hay
Figure 6 depicted that all the feedstuffs captured therein were available all the year round except wheat straw that was obtainable in the months of August to November. This non availability of wheat straw could be due to the seasonality of wheat production at the cold period of the year. However, those that were available all the year round had relative short supply between April and August because the crops are grown within this period.

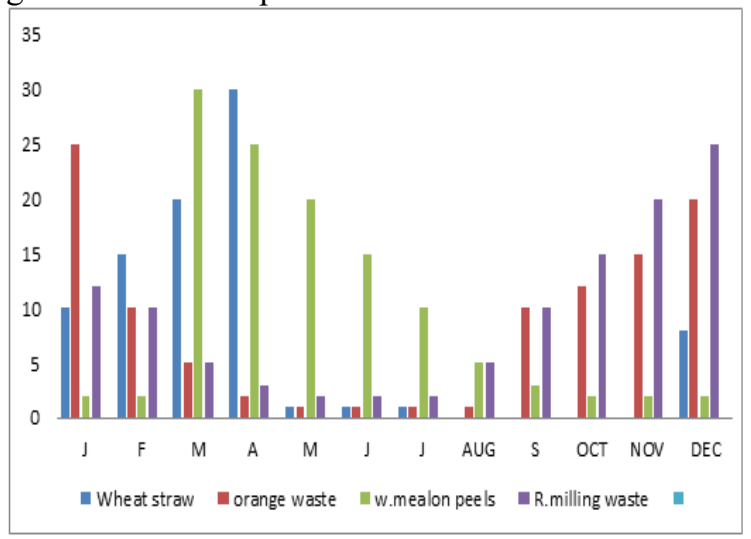

Fig 6: Availability of wheat straw, orange waste, water melon peels, rice milling waste

Figure 7 showed that banana waste was only available from October to December due to the fact banana is not usually grown in the area of study and that is period when banana is brought in large quantity there for sale. Cowpea bran was available throughout the year but mostly available from November to December. Palm kernel nut is only available from May to June which is offseason time that many people in the community travels to sell their farm produce and in turn buy palm kernel nut that are processed and used to feed the animals.

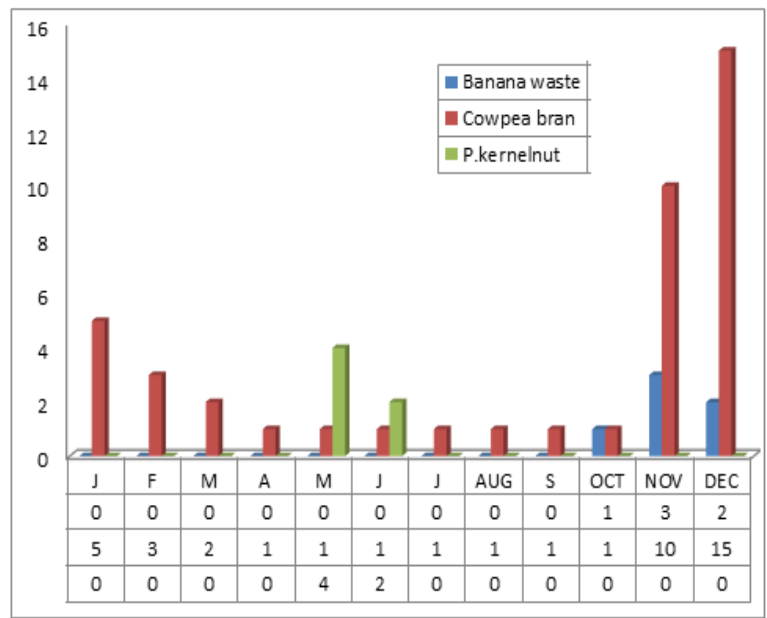

Fig 7: Availability of Banana waste, Cowpea bran, palm kernel nut

The availability of maize bran, soybean bran, millet husk, and cowpea husk and soybean meal is shown in fig 8. All these feed stuffs were revealed to be 
available throughout the year except millet husk that were obtainable April to August.

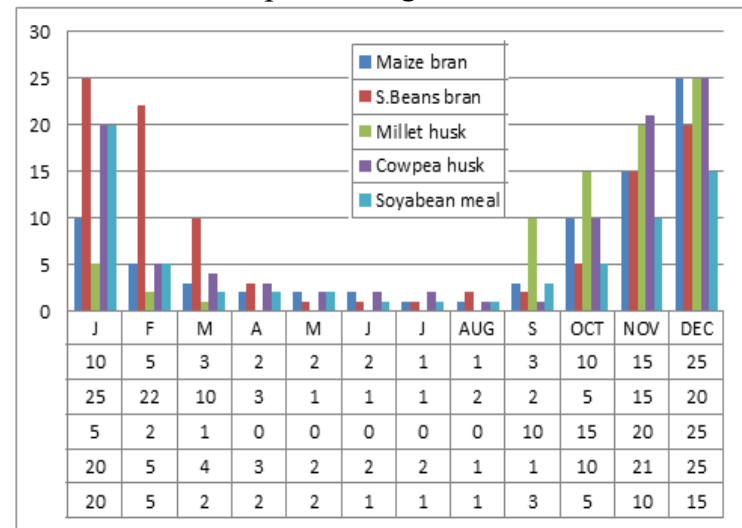

Fig 8: Availability of maize bran, millet husk, cowpea husk, soyabean meal, soyabean bran

Conclusion: The conclusion of the study showed that ruminant production is of immense benefit to the rural household and improves the socio-economic status of the farmers and alleviates poverty among poor households. Farm residues, home remnants and agro allied waste were shown to have helped in alleviating the challenges of scarcity of ruminant feed especially during the dry season of the year. Although some of these feedstuff were not available at some periods of the month, a vivid picture of the time of their availability as shown in research could help the farmers to know when these feedstuffs are available and then buy at cheaper price and store for use.

Acknowledgement: This research did not receive any specific grant from funding agencies in the public, commercial, or non-for-profit sectors.

\section{REFERENCES}

Abdu, L.S., 2003. Evaluation of methionine and lysine Supplementation in Broiler finisher Ration: performance, organoleptic properties and Economic Efficiency.Msc thesis, Micheal Okpara University of Agriculture, Umudike. pp: 1-3.

Abdu, L.S., A. Anene, G.S. Ojewola, O.U. Eromaka and E.C. Okpara, 2006. Substitution value of tiger nut (Cyperus esculentus L) for Maize in Broiler finisher Diet. Proc. ASAN. Ann. Conf.N.R.C.R.I Umudike pp: 504-507.

Adama, T.Z. (2008). Towards adequate animal protein intake by the year 2020. Inaugural lecture series 11 Federal University of Technology, 24th April, 2008.

Ajayi, H.I; Olomu, J.M. and Oyedeji J.O. (2008). Potentials of African pear (Dacryodes edulis) As a feedstuff for animals. Proceedings of the 13th Annual Science Association of Nigeria (ASAN) September 15-19, 2008, ABU, Zaria, Nigeria.

Akinmutimi, A.H. (2004). Evaluation of swordbeans (canavalic gladiate) as alternative feed resource for broiler chickens. Ph.D Dissertation.Micheal Okpara University of Agriculture, Umudike, Abia state.

Aruwayo, A., Maigandi, S. A., Malami, B. S., Daneji, A. I., Saulawa, L. A., and Garba, M. G. (2013). Nutritional evaluation of alkali treated neem kernel cake fed to fattening rams. Paki. J. Nutr. 12(3), 224-228. Available online at http://www.academicjournals.org/AJAR.

Epeju, W. F. (2010). Farmers personal characteristics in assuring agricultural productivity, lessons from sweet potato farmers in Teso, Uganda. J. Trop. Agric. 44, 52-56.

FAOSTAT (2008) FAOSTAT database. Accessible via FAO home page at http://faostat.fao.org/default.aspx. Food and Agriculture Organization.

Kasanga, M.E. (2005). Contribution of local chicken income to household: A case study of Rural Women and Credit Agencies in Mvomero District, Tanzania 43-52pp.

Luquman, M., Malik, H. N., and Khan, S. A. (2006). Extent of rural women's participation in agricultural household activities. J. Agric. Soc. Sci. $1,5-9$.

Malami, B.S., Hiernaux, P.H.Y., Tukur H.M., Steinbach, J. (2006). Effect of supplementation on feed intake and liveweight of Sheep grazing Natural Range and crop fields of Zamfara reserve in semi-arid Nigeria. Trop. J. Anim. Sci. 9 (2), 107117.

Nganga, S. K.; Kungu, J.; Ridder, N. de; Herrero, M. (2010). Profit efficiency among Kenyan smallholders' milk producers: a case study of Meru-South district, Kenya. Afr. J. Agric. Res. 5(5):332-337.

NPC (2006).National Population Commission of Nigeria. National Bureau of Statistics, https://www.nigeriastat.gov.ng.

Okali, C. and Sumberg, J.E. (1984)._Sheep and goats, men and women 'Paper prepared for the 
Conference on Intra-household Process and Farming System Analysis, Bellagio, Italy, 5-9 March 1984.

Olujenyo, F. O. (2008). The determinants of agricultural production and profitability in Akoko Land, Ondo-State, Nigeria. J. Soc. Sci. 4(1), 37-41.
S. K. Nganga, J. Kungu, N. de Ridderand M. Herrero (2010). Profit efficiency among Kenyan smallholders milk producers: A case study of Meru-South district, Kenya. Afr. J. Agric. Res. 5(4). 332-337.

Ukpabi, U.H. and Abdu, L.S. (2009). Effect of Mucuna seed meal on Dry matter intake and haematology of lactating African Dwarf Goats. Nigerian Society of Animal Production.34th Annual Conference. Uyo, Nigeria. Pp. 562-564. 